\title{
Article \\ Connexin43 in Germ Cells Seems to Be Dispensable for Murine Spermatogenesis
}

\author{
Kristina Rode ${ }^{1}$, Marion Langeheine ${ }^{1}\left(\mathbb{D}\right.$, Bettina Seeger $^{2}\left(\mathbb{D}\right.$ and Ralph Brehm ${ }^{1, *} \mathbb{(}$ \\ 1 Institute of Anatomy, University of Veterinary Medicine Foundation, 30173 Hanover, Germany; \\ kristina.rode@tiho-hannover.de (K.R.); marion.langeheine@tiho-hannover.de (M.L.) \\ 2 Institute for Food Quality and Food Safety, University of Veterinary Medicine Foundation, \\ 30173 Hanover, Germany; Bettina.seeger@tiho-hannover.de \\ * Correspondence: ralph.brehm@tiho-hannover.de; Tel.: +49-511-8457215
}

Citation: Rode, K.; Langeheine, M. Seeger, B.; Brehm, R. Connexin43 in Germ Cells Seems to Be Dispensable for Murine Spermatogenesis. Int. J. Mol. Sci. 2021, 22, 7924. https:// doi.org/10.3390/ijms22157924

Academic Editor: Mathieu Vinken

Received: 24 March 2021

Accepted: 21 July 2021

Published: 25 July 2021

Publisher's Note: MDPI stays neutral with regard to jurisdictional claims in published maps and institutional affiliations.

Copyright: (C) 2021 by the authors Licensee MDPI, Basel, Switzerland. This article is an open access article distributed under the terms and conditions of the Creative Commons Attribution (CC BY) license (https:// creativecommons.org/licenses/by/ $4.0 /)$.

\begin{abstract}
Testicular Connexin43 (Cx43) connects adjacent Sertoli cells (SC) and SC to germ cells (GC) in the seminiferous epithelium and plays a crucial role in spermatogenesis. However, the distinction whether this results from impaired inter-SC communication or between GC and SC is not possible, so far. Thus, the question arises, whether a GC-specific Cx43 KO has similar effects on spermatogenesis as it is general or SC-specific KO. Using the Cre/loxP recombinase system, two conditional $\mathrm{KO}$ mouse lines lacking Cx43 in premeiotic (pGCCx43KO) or meiotic GC (mGCCx43KO) were generated. It was demonstrated by qRT-PCR that Cx43 mRNA was significantly decreased in adult pGCCx43KO mice, while it was also reduced in mGCCx43KO mice, yet not statistically significant. Body and testis weights, testicular histology, tubular diameter, numbers of intratubular cells and Cx43 protein synthesis and localization did not show any significant differences in semi-quantitative Western blot analysis and immunohistochemistry comparing adult male KO and WT mice of both mouse lines. Male KO mice were fertile. These results indicate that Cx43 in spermatogonia/spermatids does not seem to be essential for successful termination of spermatogenesis and fertility as it is known for Cx43 in somatic SC, but SC-GC communication might rather occur via heterotypic GJ channels.
\end{abstract}

Keywords: Connexin43; spermatogenesis; testis; male germ cells; Sertoli cell; gap junction; intercellular communication

\section{Introduction}

Spermatogenesis, as a highly regulated process of mitosis and meiosis, requires intensive regulation to synchronize processes of germ cell (GC) proliferation, migration and differentiation. Besides endocrine, paracrine and autocrine regulation, intercellular communication via gap junctions (GJ) is essential for the completion of normal spermatogenesis [1,2]. GJs are intercellular plasma membrane channels allowing for direct electric and metabolic coupling of the connected cells. GJ-mediated communication can occur between cells of the same cell type (homocellular) or between different cell types (heterocellular). The constituting proteins of GJ channels are connexins (Cxs). Cxs are composed of four transmembrane domains, two extracellular loops, one cytoplasmic loop and the cytoplasmic N-and C-terminus. Forming a GJ channel between two cells, each participating cell contributes one hemichannel (=connexon) at opposing plasma membranes, which in turn consists of six Cx [3-5]. Besides classical GJ intercellular communication (GJIC), GJs are also able to provide GJ mediated cell adhesion independent from their channel function, which is critical for cell migration [6-8].

In mice, the expression of at least 19 different $C x$ genes could be identified [9]. In testicular GC of rats, transcripts of Cx26, $-31,-32,-33,-37,-40,-43,-45$ and -50 have been identified [10]. In mammalian testes, the predominant $C x$ is $C \times 43$, which can be found between Leydig cells, peritubular cells, SC and GC, namely spermatogonia, spermatocytes and spermatids [10-19]. So far, the knowledge about the specific roles of Cx43 in GC is very 
limited. Several authors have shown that, besides in SC-SC communicating junctions, Cx43 is also present in different GC populations (spermatogonia, spermatocytes and spermatids) and that it forms functional GJ between those GC and SC [10-14,16,20-23]. Among themselves, GCs communicate by intercellular bridges due to incomplete cytokinesis [24,25], which allows the transmission of substances from SC via GJ to an entire GC clone [16].

To investigate the role of $\mathrm{C} \times 43$ within the testis, different animal models were developed. In mice showing a general knockout $(\mathrm{KO})$ of $\mathrm{Cx} 43$, the offspring were not viable and died at birth due to cardiopulmonary malformations [26]. Investigations of fetal testes of those $\mathrm{KO}$ mice revealed reduced testicular weight and a decrease in GC number as compared to wild type (WT) control testes. The authors suggested that Cx43 GJ might be determinant for the migration, proliferation and/or survival of primordial GC [27]. Accordingly, Francis and Lo (2006) could show that primordial GCs are GJ communication competent cells with dye coupling being markedly reduced in $\mathrm{Cx} 43 \mathrm{KO}$ mice. They also demonstrated that primordial GC apoptosis was increased indicating that Cx43 might be essential for primordial GC survival [28]. To examine the postnatal gonadal development, testes of $\mathrm{Cx} 43$ deficient mice were grafted under the kidney capsule of normal adult mice. The reported neonatal GC deficiency persisted postnatally resulting in a "Sertolicell-only" (SCO) phenotype. These data lead to the assumption that intercellular communication between SC and GC via Cx43 GJ is also required for postnatal male germ line development [29].

As general Cx43 KO mice are not viable and postnatal testicular development is therefore hard to investigate, our and another working group independently established a conditional $\mathrm{KO}$ mouse line using the Cre/loxP recombinase system [30], in which the Gja1 gene (Gap junction protein alpha 1; coding for Cx43) is knocked out only in somatic SC (SCCx43KO) [31,32]. Male KO mice are viable, but infertile. Using these SCCx43KO mice, the critical role of $\mathrm{C} \times 43$ in SC for spermatogenesis has been emphasized. Male KO mice showed reduced testis size and weight, significantly reduced GC numbers, about $95 \%$ tubules with arrested spermatogenesis, SCO morphology and/or intratubular cell clusters and consequently infertility [31-33]. GJ coupling and Cx43 levels were reduced compared to WT testes and reduced $\mathrm{Cx} 43$ levels were associated with, e.g., altered expression of components of the blood-testis barrier [34-36]. As shown by various studies, of our research group, the $\mathrm{KO}$ of $\mathrm{Cx} 43$ in SC has drastic effects on the number, differentiation and gene regulation of GC and consequently also on spermatogenesis [31,37]. Until now, it is not possible to discriminate, if these profound changes of testicular function observed in mice with a general or $\mathrm{SC}$ specific $\mathrm{KO}$ of $\mathrm{Cx} 43$ result from altered communication only between SC or also between SC and GC. Therefore, the question arises, whether there is a similar effect if the Gja1 gene is knocked out only in GC using efficient and reliable GC specific Cre lines (Figure 1). 

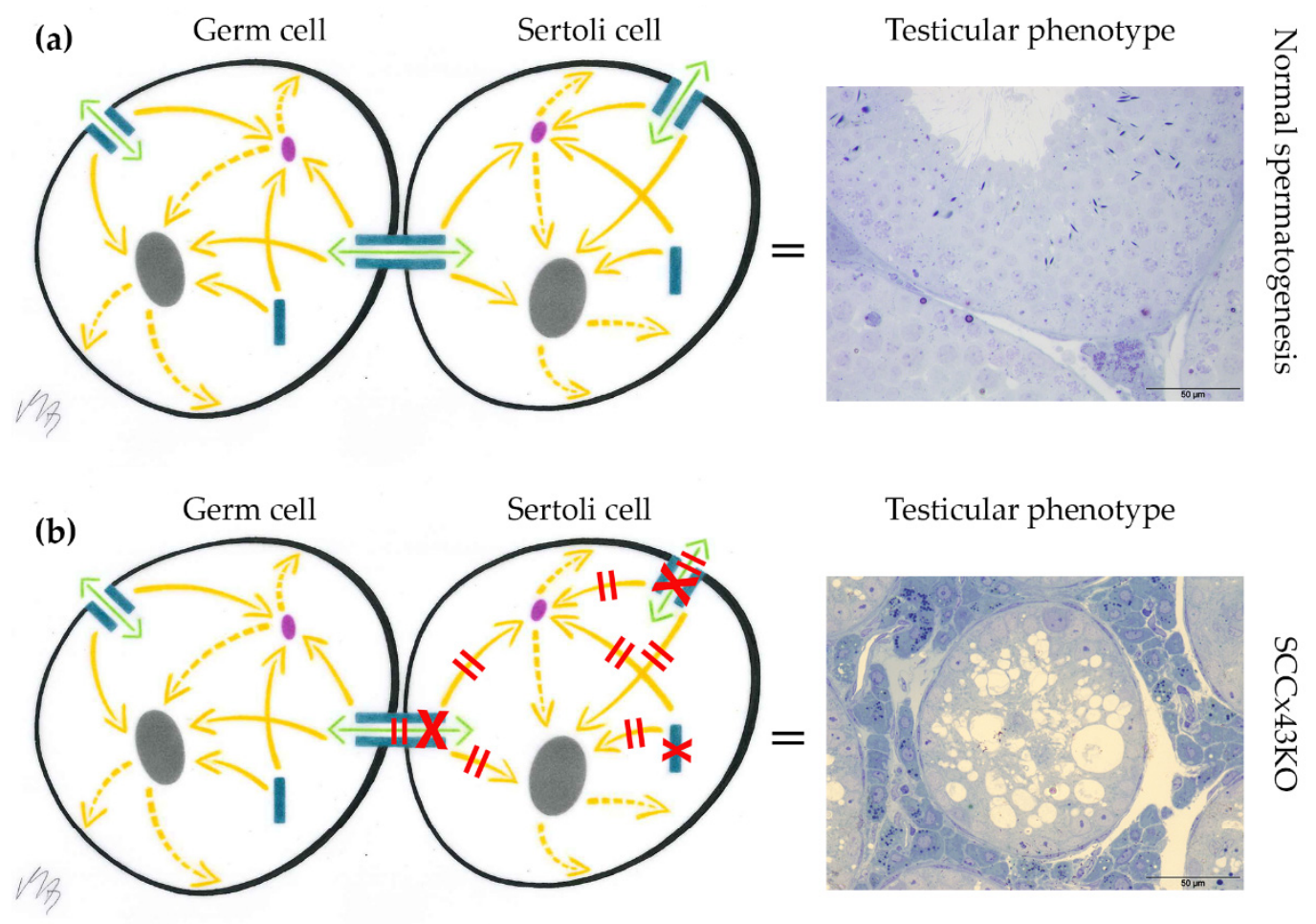

Testicular phenotype

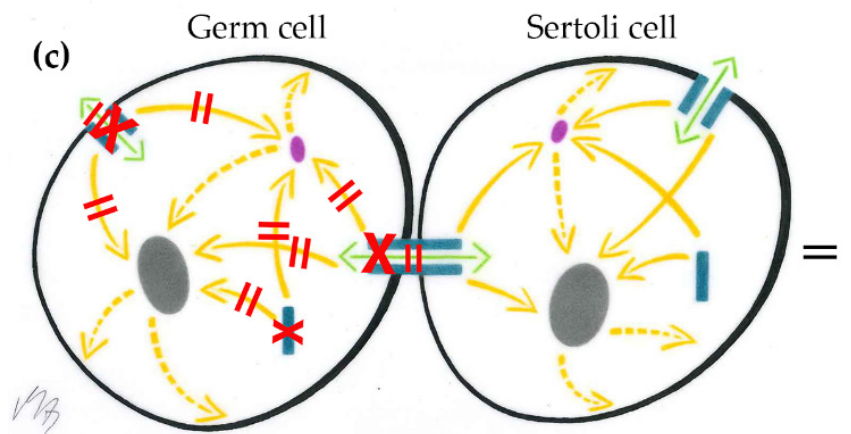

Testicular phenotype

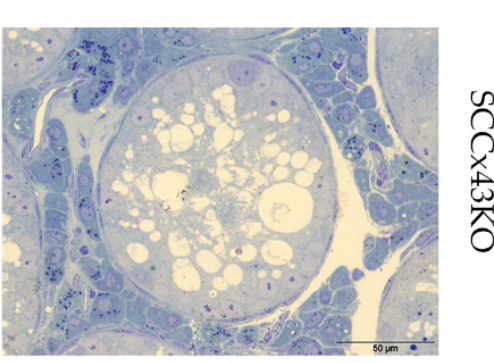

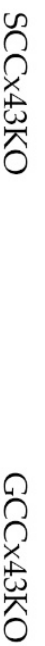

Legend:

$$
\begin{aligned}
\text { I } & =\mathrm{C} \times 43 \\
\text { II } & =\text { connexon (= hemichannel) } \\
& =\text { nucleus } \\
& =\text { protein } \\
X & =\text { knockout of } \mathrm{Cx} 43 \\
\| & =\text { missing effect of } \mathrm{Cx} 43
\end{aligned}
$$

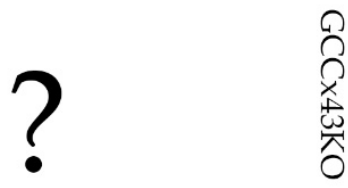

Figure 1. Background of the study. (a) Undisturbed intercellular communication between germ cells (GC) and Sertoli cells (SC) via Connexin43 (Cx43)-based gap junctions (GJ) results in normal spermatogenesis. (b) Knockout (KO) of Cx43 in SC leads to severely impaired spermatogenesis in SC specific Cx43 KO (SCCx43KO) mice. (c) The testicular phenotype of mice, which exhibit a $\mathrm{KO}$ of $\mathrm{Cx} 43$ in premeiotic or meiotic GC populations, is not confirmed, so far [38]. It is of interest to know, if a GC specific KO of Cx43 leads to a similar phenotype as the $\mathrm{KO}$ in SC. Scale bars $=50 \mu \mathrm{m}$.

A first attempt to elucidate this question was made by Günther et al. (2013), who generated a GC specific KO of Cx43 in mice using transgenic floxed Cx43 and TNAP-Cre mice leading to a Cre-mediated excision of floxed genes in primordial GC [38,39]. In this mouse model, the homozygous $\mathrm{KO}$ animals were fertile with normal spermatogenesis and did not show visible alterations of the genital tract, although immunoreactivity of Cx43 protein was decreased and Cx43 mRNA was also downregulated. Expression of other Cxs (Cx26, -45, and -33) was almost unchanged, so the authors concluded that Cx43 did not seem to be essential for GC-SC communication as long as other Cx still existed. However, 
these data can only be considered as trends as they originate only from a small number of animals. The authors mentioned a high spontaneous and unpredictable mortality rate due to unknown reasons [38]. Furthermore, the actual excision activity of the TNAP-Cre transgenic mouse line is only at around $59.8 \%$ and the excision sometimes affects other cells than primordial GC [39]. Therefore, a reason for the missing effect of spermatogenesis might be the insufficient efficiency of Cre activity in the TNAP-Cre mouse line, and ectopic Cre activity in other cells besides primordial GC might have contributed to the increased mortality rate. Both aspects made the TNAP-Cre mouse line insufficient to study the effects of a GC specific deletion of $\mathrm{Cx} 43$ further, and more suitable Cre mouse lines should be selected for this purpose. As mentioned above, functional Cx43 based GJs were at least found in spermatogonia and spermatocytes $[13,16,21,22]$, so a Cre line targeting specifically those cell types should be appropriate. The stimulated by retinoic acid gene 8 (Stra8)Cre expression is limited to spermatogonia and preleptotene spermatocytes starting on postnatal day 3 throughout adulthood, before $\mathrm{C} \times 43$ protein concentrates at the blood-testis barrier from day 12 onwards in normal mice [35,40]. With an efficiency of $>95 \%$, it is considered to be ideal for studying effects of gene loss in those cell types [41,42]. In order to investigate the influence of Cx43-based GJ communication of meiotic GC, the use of protamine-1 (Prm1)-Cre might be useful, which starts to be expressed in haploid spermatids and is $>92 \%$ efficient $[42,43]$.

Thus, aims of the present study were, (1) the establishment of two new conditional $\mathrm{KO}$ mouse lines with a GC specific deletion of $\mathrm{Cx} 43$ either in premeiotic spermatogonia and early spermatocytes (pGCCx43KO) or in meiotic spermatids (mGCCx43KO) using the Cre/LoxP recombination system to cover the entire postnatal male GC population, (2) investigation of functions of $\mathrm{Cx} 43$ in these specific GC populations, and (3) elucidation of possible consequences of the $\mathrm{KO}$ of $\mathrm{Cx} 43$ in male GC on testicular development and spermatogenesis. Based upon the present data, $\mathrm{KO}$ of $\mathrm{Cx} 43$ in spermatogonia (pGCCx43KO) or spermatids (mGCCx43KO) did not seem to have dramatic impacts on testicular histology and successful completion of spermatogenesis in adult mice, as it is known for $\mathrm{Cx} 43$ in somatic SC [31-33,35-37,44-46]. This might be because GC-Cx43 is not essential for successful spermatogenesis or due to compensation by another, yet not identified, Cx in GC forming heterotypic GJ channels with Cx43 in SC.

\section{Results}

\subsection{Determination of the Genotype}

\subsubsection{PCR Genotyping}

PCR genotyping using gDNA of mouse ear tissue was performed within the first 14 days of life. Samples were investigated regarding Cre and lox/P site expression. The following genotypes were used for further investigations:

- Cre positive and both alleles of the Gja1 gene flanked by lox/P sites ("homoflox") mice were considered as homozygous $\mathrm{KO}$ mice

- Cre negative mice were considered as WT mice.

Representative results are shown in Figure 2a,b. 
(a)

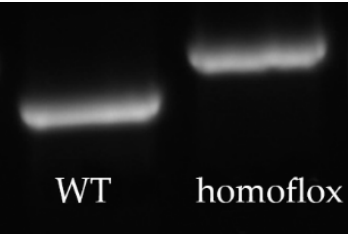

$1000 \mathrm{bp}$

(b)

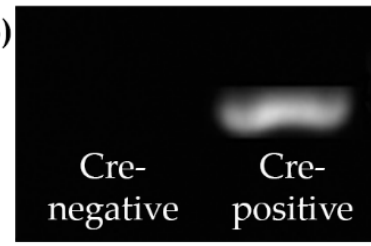

(c)

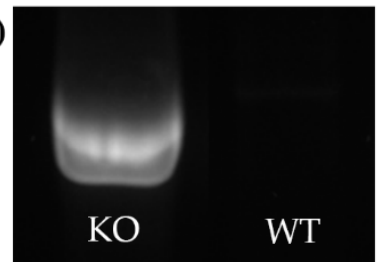

$700 \mathrm{bp}$

Figure 2. Representative images of PCR genotyping (a,b) and Connexin (Cx43)-del PCR (c). (a) Identification of loxP site expression showing no loxP site (=wild type [WT]) and both alleles flanked by loxP sites ("homoflox"); (b) Identification of Cre expression with Cre- negative mice showing no band and Cre-positive mice showing a single band at approximately 470 base pairs (bp) (given example was from premeiotic germ cell specific Cx43 knockout (KO) (pGCCx43KO) mice); (c) Confirmation of the deletion of Cx43 in testis homogenate was performed by Cx43-del PCR. Primers generated a $670 \mathrm{bp}$ amplicon in $\mathrm{KO}$ but not in WT mice (given example was from pGCC 43 KO mice).

\subsubsection{Cx43-del PCR}

To confirm deletion of the floxed Gja1 alleles in gDNA of testis homogenate, Cx43-del PCR was performed using specific primers generating a $670 \mathrm{bp}$ amplicon of the junction between the intron of $\mathrm{Cx} 43$ and the lac $Z$ coding region in mice, which lost the $\mathrm{Cx} 43$ coding region according to Brehm et al. (2007) [31]. The confirmation of the KO by Cx43-del PCR was successful and representative results are shown in Figure 2c.

\subsection{Body and Testis Weight}

During dissection of adult male mice, body and total testis weight were determined and relative testis weight was calculated. Mean values were compared between KO and WT. No significant differences could be determined regarding body and total testis weight as well as relative testis weight (Figure 3). 

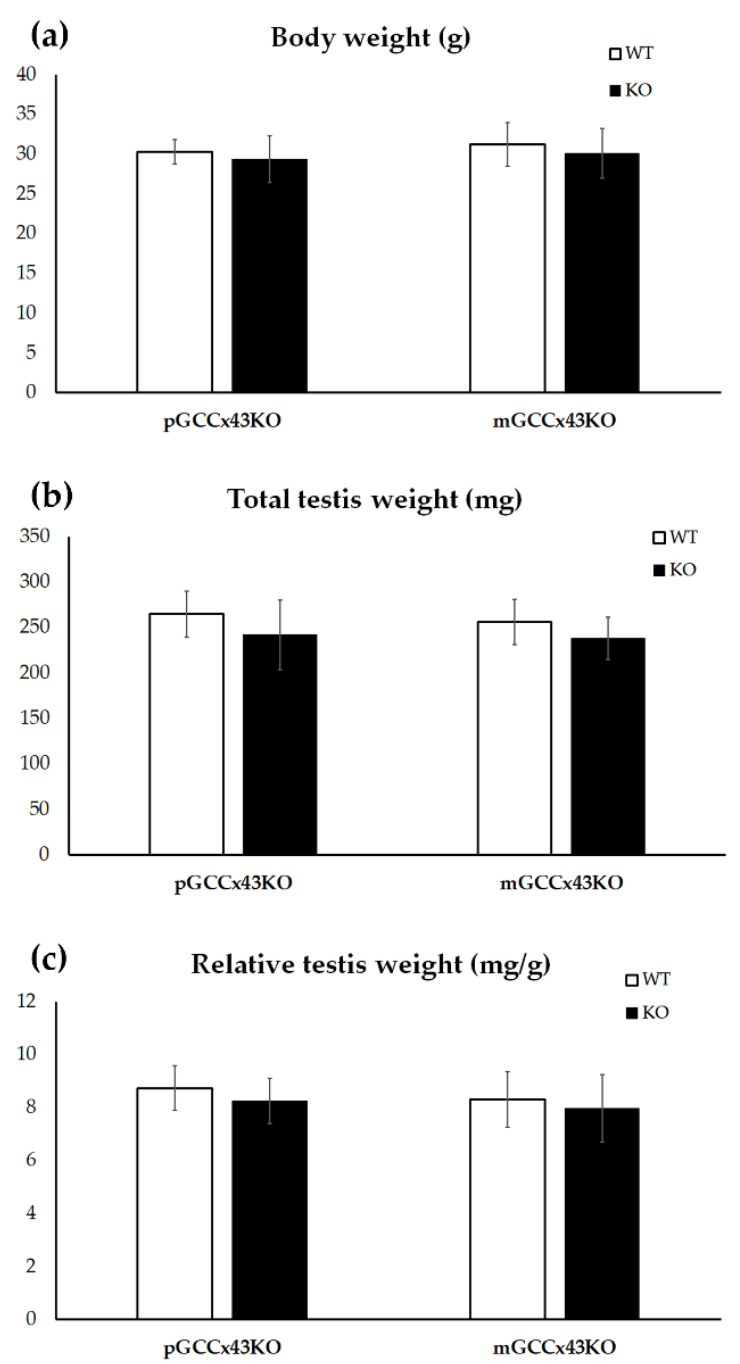

Figure 3. Graphical depiction of the comparison of body weight (a), total testis weight (b) and relative testis weight $(\mathbf{c})$ between knockout $(\mathrm{KO})$ and wild type (WT) mice. No significant differences of the body weight (a), the total testis weight $(\mathbf{b})$ and the relative testis weight $(\mathbf{c})$ could be observed between KO and WT in premeiotic germ cell (GC) specific Connexin43 (Cx43) KO (pGCCx43KO) and meiotic GC specific $\mathrm{Cx} 43 \mathrm{KO}(\mathrm{mGCCx} 43 \mathrm{KO})$ mice. Data are given as mean \pm standard deviation.

\subsection{Histology and Immunohistochemistry}

\subsubsection{Hematoxylin-Eosin (HE) Staining and Tubular Diameter}

In HE stained sections, no obvious alterations of spermatogenesis in adult $\mathrm{KO}$ male mice were visible compared to corresponding WT littermates (Figure 4). Furthermore, the mean diameter of seminiferous tubules did not differ significantly comparing adult $\mathrm{KO}$ and WT animals of both mouse lines, respectively (Figure 5). Original data can be found in Supplemental Table S1 and Supplemental Table S2. 

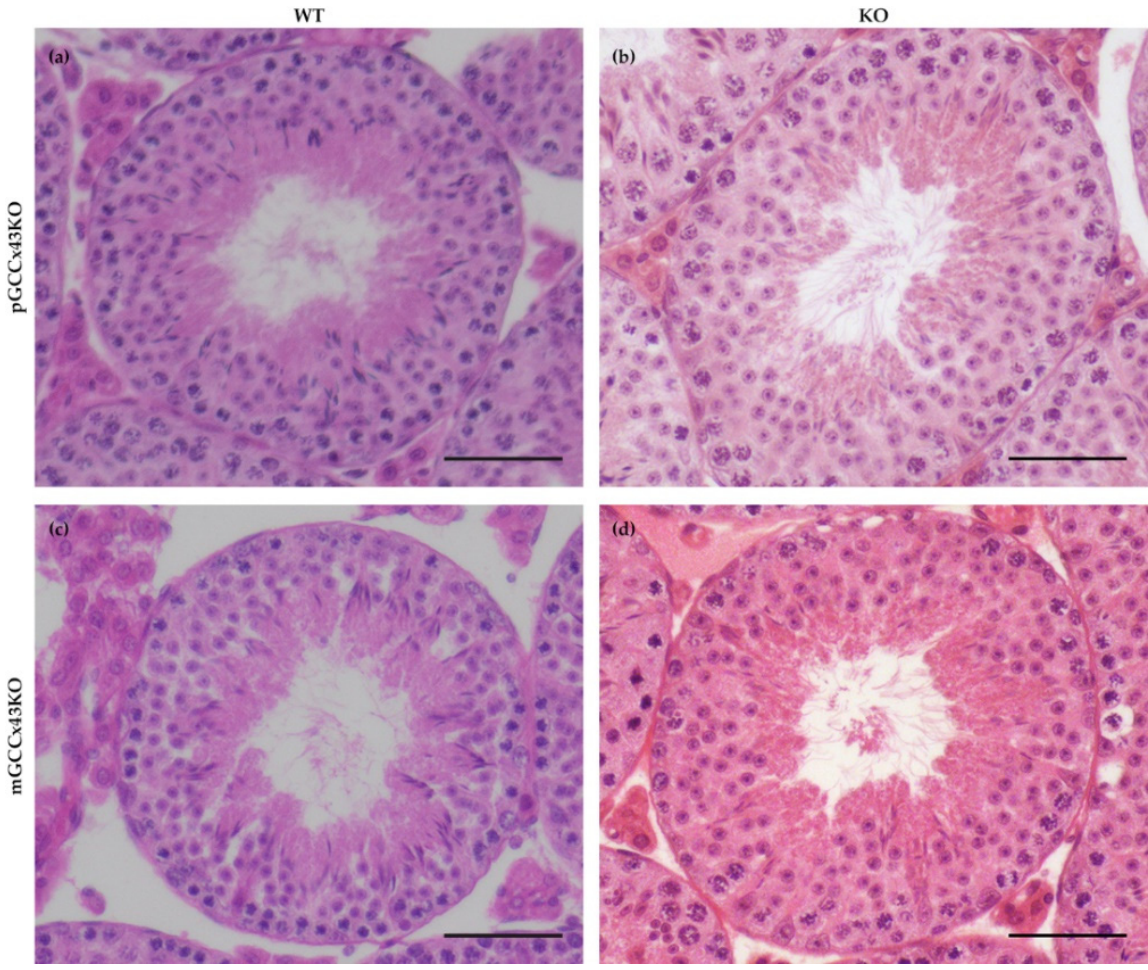

Figure 4. Representative images of a seminiferous tubule of adult wild type (WT) $(\mathbf{a}, \mathbf{c})$ and knockout $(\mathrm{KO})(\mathbf{b}, \mathbf{d})$ premeiotic germ cell (GC) specific KO of Connexin43 (Cx43) (pGCCx43KO; (a,b)) and meiotic GC specific KO of Cx43 (mGCCx43KO; c,d) mice. No obvious differences in testicular morphology and spermatogenesis were visible between $\mathrm{KO}$ and $\mathrm{WT}$, when $\mathrm{Cx} 43$ was knocked out in either premeiotic $(\mathbf{a}, \mathbf{b})$ or meiotic $(\mathbf{c}, \mathbf{d})$ GC. Hematoxylin eosin staining; scale bars $=50 \mu \mathrm{m}$.
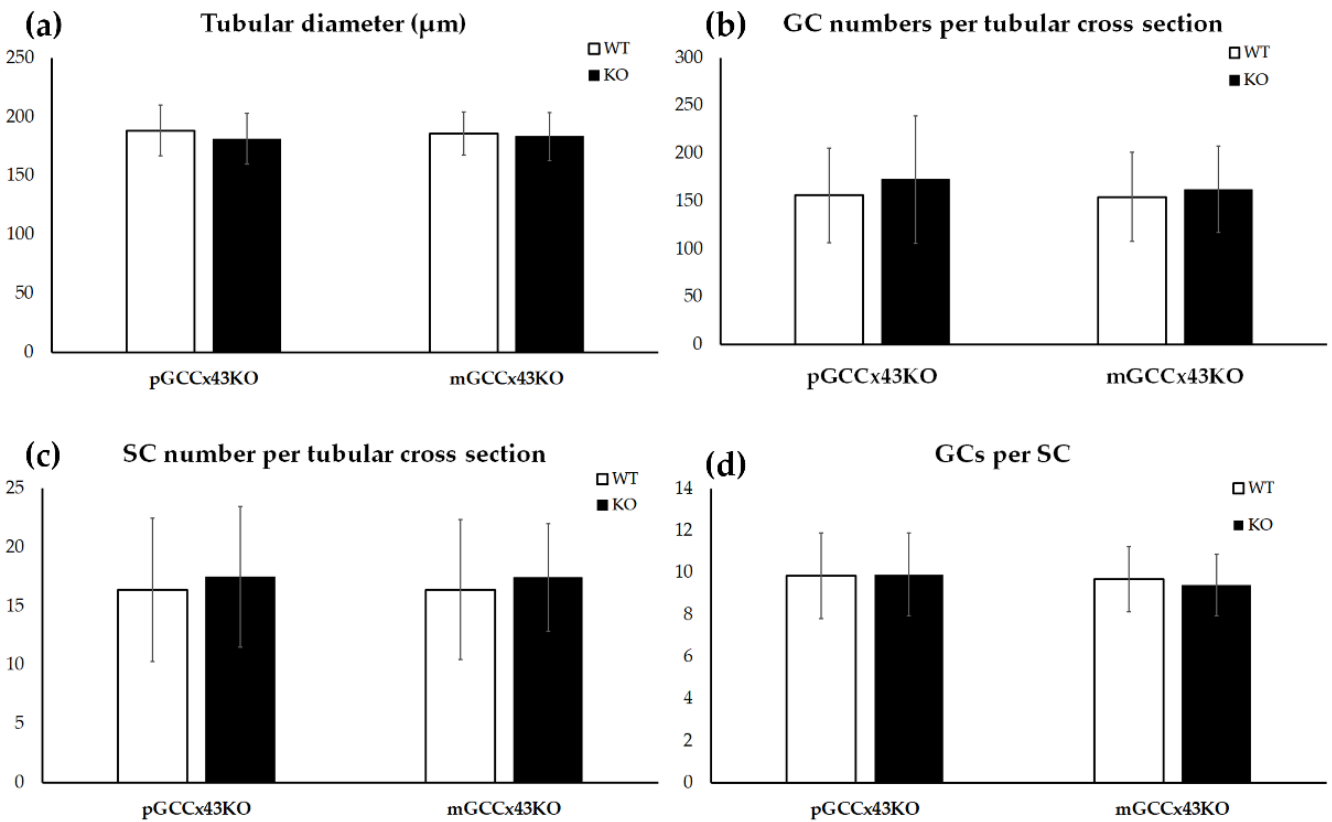

Figure 5. Graphical depiction of the comparison of the tubular diameter (a), germ cell (GC) numbers per tubular cross section (b), Sertoli cell (SC) numbers per tubular cross section (c) and calculated GC/SC ratio per tubular cross section (d) between knockout $(\mathrm{KO})$ and wild type (WT) mice. No significant differences in any of the examined parameters could be observed between $\mathrm{KO}$ and WT in premeiotic GC specific KO of Connexin43 (Cx43) (pGCCx43KO) and meiotic GC specific KO of Cx43 $(\mathrm{mGCC} 43 \mathrm{KO})$ mice. Data are given as mean \pm standard deviation. 


\subsubsection{Cx43 Localization}

Specific immunoreaction of $\mathrm{C} \times 43$ protein was found in the basal area of the seminiferous epithelium of adult WT and KO mice of both GCCx43KO mouse lines using IHC. No obvious differences between WT and KO male mice could be observed. As other cell types remain unaffected by the deletion of $\mathrm{Cx} 43$, this staining pattern probably represents $\mathrm{C} \times 43$ GJ between adjacent SC at the level of the BTB (Figure 6).
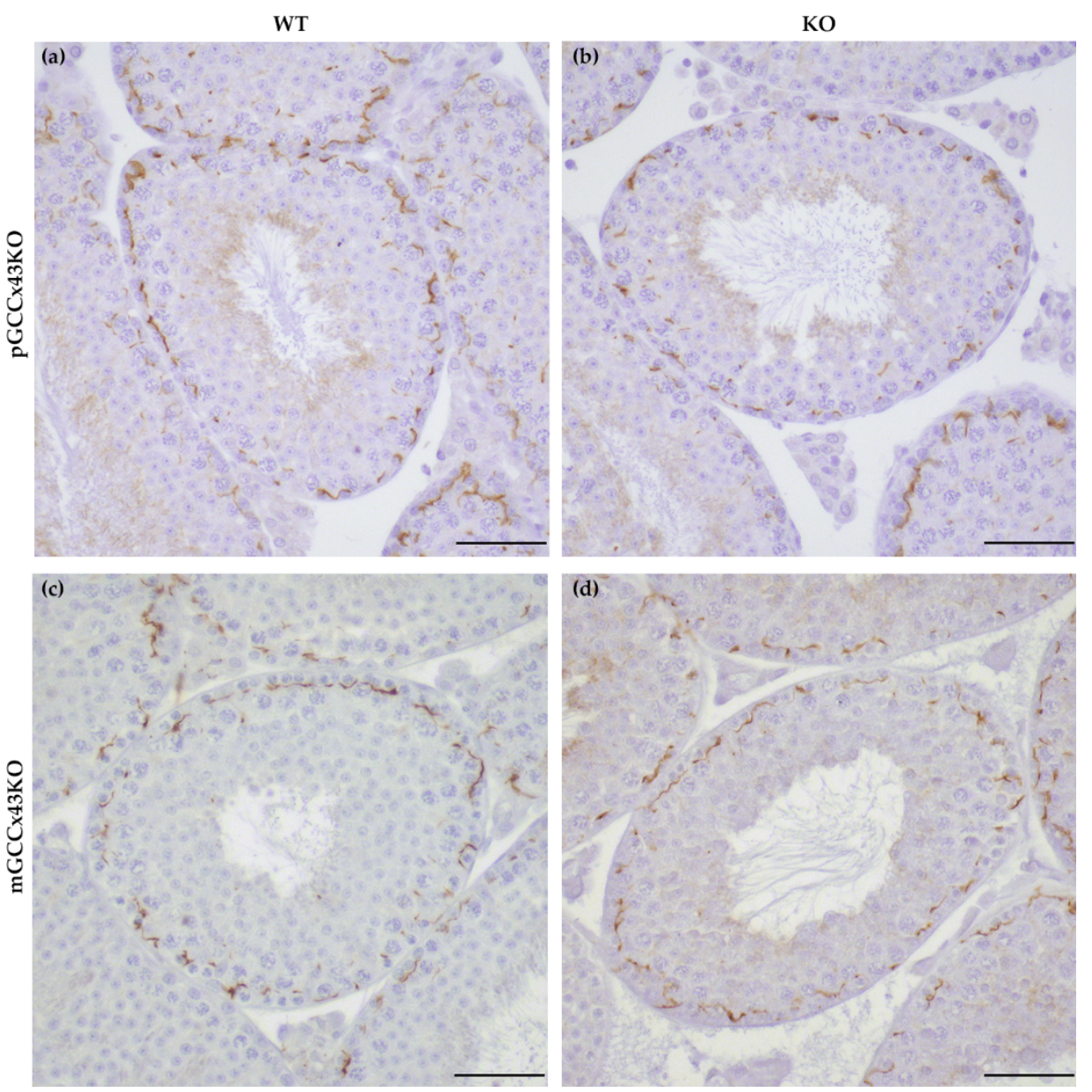

Figure 6. Immunohistochemical detection of Connexin43 (Cx43) protein in adult testes of wild type $(\mathrm{WT} ;(\mathbf{a}, \mathbf{c}))$ and knockout $(\mathrm{KO} ;(\mathbf{b}, \mathbf{d}))$ mice of the premeiotic germ cell (GC) specific KO of Cx43 (pGCCx43KO; (a,b)) and meiotic GC specific Cx43 KO (mGCCx43KO; (c,d)) mouse line. No obvious differences were visible between $\mathrm{KO}$ and $\mathrm{WT}$, when $\mathrm{Cx} 43$ was knocked out in either premeiotic $(\mathbf{a}, \mathbf{b})$ or meiotic (c,d) GC. Scale bars $=50 \mu \mathrm{m}$.

Using more sensitive immunofluorescence (IF) analysis of Cx43 localization, it was visible that $\mathrm{C} \times 43$ forms a fine linear staining pattern in the basal area of the seminiferous tubules in WT mice of both mouse lines resulting from synthesis by both Sertoli cells and basally located germ cells (Figure 7, arrow in a). Furthermore, Cx43 can also be found more apically in the seminiferous epithelium (Figure 7, arrow in c) in WT mice. In the KO animals of the pGCCx43KO mouse line (Figure $7 \mathrm{~b}$ ), the described staining pattern in the basal area of the seminiferous epithelium is also visible, however, the staining intensity seems to be less intense, probably resulting from the lack of $\mathrm{Cx} 43$ in the basally located germ cells due to the $\mathrm{KO}$ in premeiotic GC. In the mGCCx43KO mouse line (Figure 6d), the apical localization of $\mathrm{C} \times 43$ could not be detected (Figure 7d) indicating that the more apically localized germ cells (spermatids) may not synthesize $\mathrm{C} \times 43$ following its $\mathrm{KO}$ in meiotic GC. 

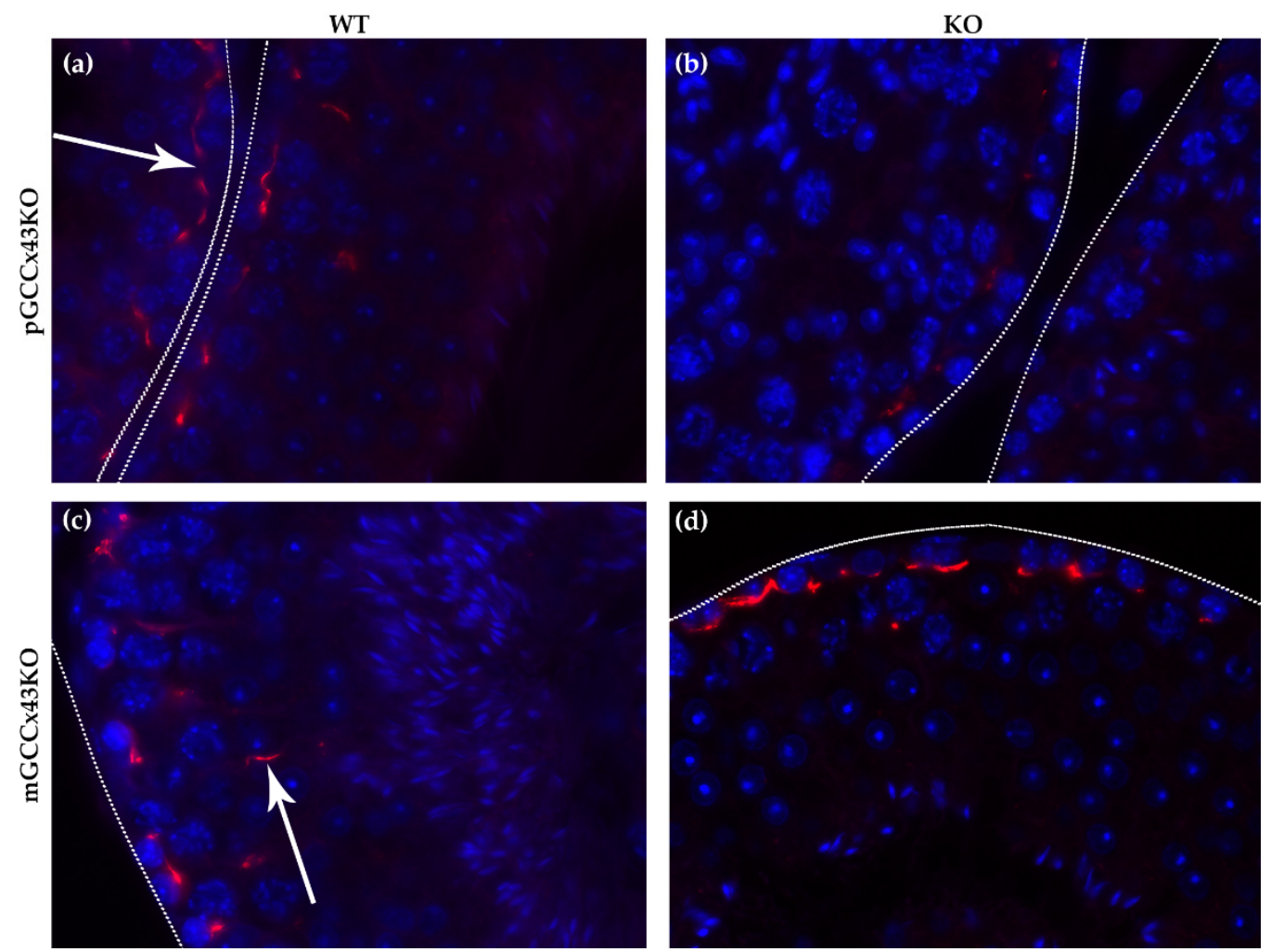

Figure 7. Representative localization of Connexin43 (Cx43) in adult p- and mGCCx43KO and WT mice. For easier orientation, the basal lamina of the tubules is marked by dotted lines. Cx43 forms a fine linear staining pattern (red) in the basal area of the seminiferous tubules (arrow in (a)) in WT mice of both mouse lines $(\mathbf{a}, \mathbf{c})$ resulting from synthesis by both Sertoli cells and basally located germ cells. Furthermore, $\mathrm{Cx} 43$ can also be found more apically in the seminiferous epithelium (arrow in (c)) in WT mice. In the KO animals of the pGCCX43KO mouse line (b), the described staining pattern in the basal area of the seminiferous epithelium is also visible; however, the staining intensity seems to be less intense, probably resulting from the lack of Cx43 in the basally located germ cells due to the KO in spermatogonia/early spermatocytes. In the mGCCx43KO mouse line (d), the apical localization of $\mathrm{Cx} 43$ could not be detected indicating that the more apically localized germ cells (spermatids) do not synthesize Cx43 following its $\mathrm{KO}$ in those cell types. Magnification: $630 \times$.

Furthermore, using immunogold labeling and subsequent transmission electron microscopy (TEM), the loss of Cx43 could also be confirmed (Supplemental Figures S2-S5).

\subsubsection{Sox9-Staining and GC and SC Numbers}

Numbers of SC and GC per tubular cross section were determined in immunohistochemically stained testicular sections using the primary anti-Sox 9 antibody, which represents an SC marker and allows an accurate distinction of SC and GC (Supplemental Figure S1). In adult mice of both GCCx43KO mouse lines, SC and GC numbers did not differ significantly between genotypes and consequently, also the GC:SC ratio was not significantly different (Figure 5).

\subsection{Semi-Quantitative Western Blot Analysis}

The semi-quantitative WB analysis of three adult mice per genotype of each mouse line with $\alpha$-tubulin as a loading control showed no significant differences in the amount of Cx43 protein in testis homogenate of $\mathrm{KO}$ and WT mice (Figure 8). 

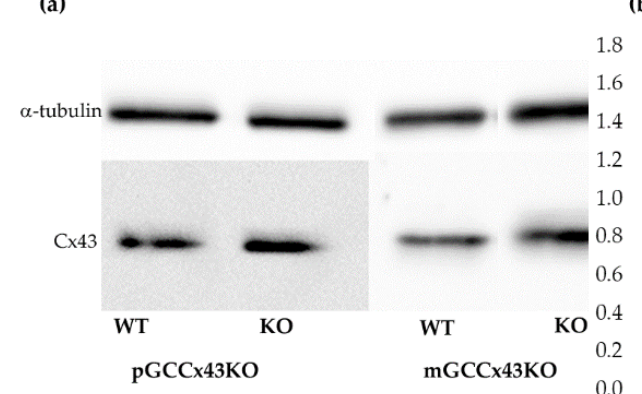

pGCCx43KO

mGCCx43KO

0.0

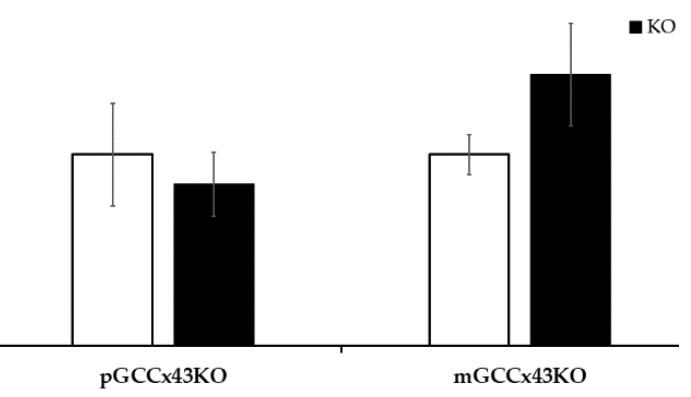

Figure 8. Representative Western blot of Connexin43 (Cx43) (43 kilodalton [kDa]) (a) and the corresponding semi-quantitative evaluation by densitometry (b) using testis homogenate. $\alpha$-tubulin (52 kDa) was used as loading control (housekeeper). No significant differences in the relative protein amount of Cx43 could be determined comparing knockout (KO) and wild type (WT) mice of both mouse lines.

\section{5. $q R T-P C R$}

To quantify mRNA expression, qRT-PCR of different $C x$ family members known to be expressed in GC, namely Gja1 (coding for Cx43), Gjc1 (gap junction protein gamma 1; coding for Cx45), and Gja6 (gap junction protein alpha 6; coding for Cx33) was performed. Gja1 expression was significantly downregulated in pGCCx43KO mice (Figure 9), which was an expected finding due to its deletion in premeiotic GC. However, in mGCCx43KO mice, Gja1 was also reduced, yet not statistically significant, maybe because the amount of Cx43 mRNA in meiotic GC does not contribute significantly to the total amount of Cx43 mRNA in whole testis homogenate. To identify possible compensatory increases of other Cx types expressed in GC, mRNA expression of Cx33 and Cx45 was also investigated, but no significant differences could be observed comparing $\mathrm{KO}$ and WT testes of both $\mathrm{p}$ - and mGCCx43KO mice (Figure 9). Original data can be found in Supplemental Table S3.
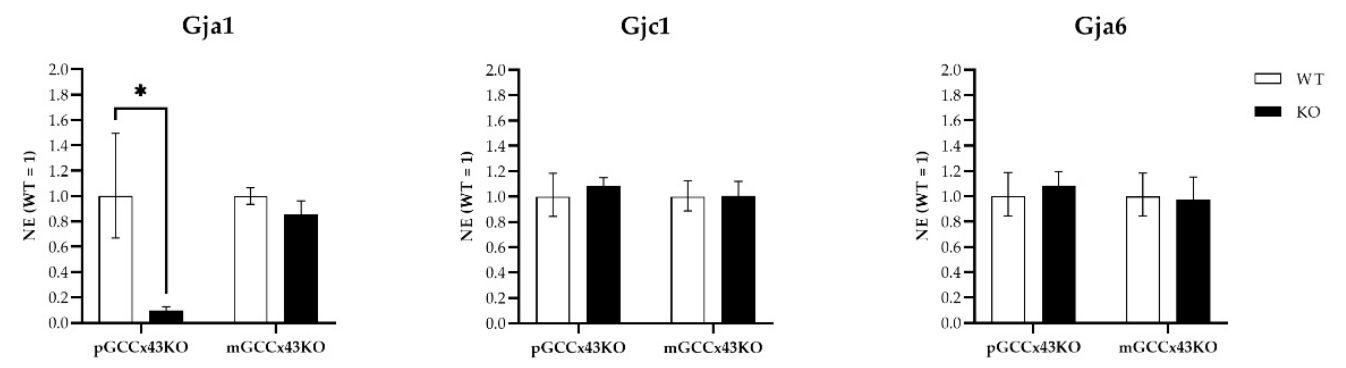

Figure 9. qRT-PCR of gap junction protein alpha 1 (Gja1; coding for Connexin43 [Cx43]), gap junction protein gamma 1 (Gjc1; coding for Cx45) and gap junction protein alpha 6 (Gja6; coding for Cx33). mRNA of Gja1 was significantly decreased $\left({ }^{*} p<0.05\right)$ following the knockout $(\mathrm{KO})$ of $\mathrm{Cx} 43$ in adult premeiotic germ cell (GC) specific KO of C43 (pGCCx43KO) mice, while it was only slightly reduced in meiotic GC specific KO of Cx43 (mGCCx43KO) mice. Gjc1 and Gja6 mRNA did not differ significantly between genotypes in both p- and $\mathrm{mGCC} 43 \mathrm{KO}$ mice. Data are given as geometric mean \pm geometric standard deviation.

\subsection{Mating Experiments}

Fertility assessment of homozygous $\mathrm{KO}$ males of both mouse lines revealed no obvious disturbance of mating behavior or fertility. Male $\mathrm{KO}$ mice were able to produce offspring within six weeks with an average litter size of six pups. 


\section{Discussion}

Several studies have shown that Cx43 is essential for spermatogenesis [27-29,31-37,44-47]. However, the contribution of known hemichannels provided by GC to this important role could not be determined and consequently is unknown so far. With the present study, we addressed this issue by creating GC specific $\mathrm{KO}$ of the predominant testicular GJ protein $\mathrm{C} \times 43$. Two new conditional $\mathrm{KO}$ mouse lines lacking the GJ protein Cx43 in different GC populations have successfully been generated using the Cre/loxP recombination system. In pGCCx43KO mice, Cx43 was knocked out in premeiotic spermatogonia and early spermatocytes using Stra8-Cre mice, whereas in mGCCx43KO mice, Gja1 was deleted in meiotic spermatids (using Prm1-Cre mice) to study the role of Cx43 based GJIC in those cell types. Using qRT-PCR, an expected reduction of Gja1 following its deletion was confirmed. The decrease of Gja1 mRNA was statistically significant in pGCCx43KO mice concomitant with previous results [38], while only a decreasing trend could be observed in mGCCx43KO mice (Figure 9). The observation that Cx43 mRNA was only slightly reduced in mGCC $43 \mathrm{KO}$ might be explained by the amount of Cx43 mRNA in meiotic GC (spermatids), which possibly does not contribute significantly to the total amount of $\mathrm{Cx} 43$ mRNA in whole testis homogenate $[10,11,13,22]$. At protein level, no significant changes of the amount of $\mathrm{Cx} 43$ could be observed using semi-quantitative WB analysis (Figure 8), and protein localization seemed to be unchanged comparing $\mathrm{KO}$ and WT animals of both mouse lines using IHC (Figure 6). However, using more sensitive methods like IF (Figure 7) and immunogold electron microscopy (Supplemental Figures S2-S5), the lack of Cx43 in either premeiotic (pGCCx43KO) or meiotic GC (mGCCx43KO) could be demonstrated. The discrepancy between mRNA and protein amount of $\mathrm{Cx} 43$ might originate from the different accuracy of semi-quantitative WB analysis and qRT-PCR, of which the latter is more reliable than semi-quantitative WB analysis. Data of the present study regarding Cx43 protein synthesis might indicate that $\mathrm{Cx} 43$ in premeiotic or meiotic GC only constitutes a small (non-significant) part of the total amount of $\mathrm{Cx} 43$, whereas deletion of $\mathrm{Cx} 43$ in $\mathrm{SC}$ results in a significant downregulation of both Cx43 protein synthesis and mRNA expression $[18,31]$. Thus, the major proportion of $\mathrm{Cx} 43$ protein in the testis seems to be provided by SC and Leydig cells $[14,15,21]$.

Unlike the $\mathrm{KO}$ of Cx43 in SC [31-33,35,45,46], its deletion in spermatogonia/early spermatocytes or spermatids did not have dramatic impacts on testicular histology and successful completion of spermatogenesis in adult p- and mGCCx43KO mice (Figures 4 and 7) confirming previous results of Günther and colleagues [38]. These authors also generated a GC specific $\mathrm{KO}$ of $\mathrm{Cx} 43$ using TNAP-Cre mice leading to a Cre-mediated excision of floxed Cx43 in primordial GC [39]. Homozygous $\mathrm{KO}$ animals were also fertile with normal spermatogenesis. In this study, expression of other $\mathrm{Cx}$ was almost unchanged, so the authors concluded that $\mathrm{Cx} 43$ did not seem to be essential for GC-SC communication if other Cxs still existed [38]. Similar results were obtained in the present study by investigating mRNA expression of other Cxs, Cx33 and Cx45, which are known to be expressed in GC $[11,13-16,21,22,48,49]$ and might be elevated to compensate for the loss of Cx43 in GC by forming heterotypic GJ channels with SC. Cx45 and Cx33 can interact with Cx43 [50,51], and thus might be able to balance out the loss of Cx43 in GC. In the present study, mRNA expression of Gjc1 (coding for Cx45) and Gja6 (coding for Cx33) did not show any significant differences between WT and $\mathrm{KO}$ animals in both p- and mGCCx43KO mouse lines, indicating that these two $\mathrm{Cx}$ members probably do not compensate for the loss of Cx43. Our results, together with those of Günther et al. [38], indicate growing evidence that $\mathrm{Cx} 43$ in GC might not play an essential role in regulating spermatogenesis. So far, implications that another $\mathrm{Cx}$ might compensate for the loss of $\mathrm{Cx} 43$ in GC are missing. The present results suggest that either SC-GC crosstalk via homotypic Cx43-based GJ is not necessary for normal termination of spermatogenesis, or that GC-Cx43 is replaced by another, yet not identified, Cx, resulting in heterotypic GJ channels. It might also be speculated that, while homotypic Cx43 based GJIC between SC is essential for spermatogenesis [31-37,44-46], SC-GC communication might normally occur via heterotypic GJ 
composed of Cx43-hemichannels supplied by SC, and connexons of GC assembled by a so far unidentified $\mathrm{Cx}$ type. If this was the case, SC-GC communication would not be affected by a GC specific Cx43 KO, but an SC specific deletion of Cx43 would impede the communication between those cell types.

Functional differences of SC-SC vs. SC-GC GJ have already been described. While GJIC can occur efficiently and bi-directionally between adjacent SC, it takes place only unidirectionally from SC to spermatogonia and late spermatocytes in rats [16,22]. Furthermore, it has been described that SC-SC coupling is nonselective, whereas GJ connection between SC and spermatogonia is strongly selective for positively charged biotin tracers compared to negatively charged Lucifer Yellow [22]. Differences in gating properties of GJ are associated with their constituting proteins [52]. It was therefore proposed that the Cxs of those selective SC-spermatogonia junctions might differ from SC-SC junctions by the connection via heterotypic channels [22]. Our results, together with findings in SCCx43KO mice, can support this suggestion as the $\mathrm{KO}$ of $\mathrm{Cx} 43$ in $\mathrm{SC}$ has drastic effects on testicular function, while its $\mathrm{KO}$ in GC does not lead to obvious alterations of spermatogenesis and fertility. It was also described that dye coupling between SC and adluminal spermatids was too weak to be detected by fluorescence microscopy, which supports our results of the Cx43 KO in meiotic GC [22]. However, the molecular composition of SC-GC junctions remains unknown.

Previous studies of our research group using SCCx43KO mice showed that deletion of the Gja1 gene in SC affects gene expression in prepubertal mice and, surprisingly, the majority of the significantly regulated genes were GC specific and involved in the regulation of the onset of meiosis $[37,44]$. This indicates a close connection between SC and GC and that Cx43 in SC participates in the regulation of GC gene expression, GC proliferation and differentiation $[37,44]$. However, it might also be possible that these changes were caused by missing channel-independent functions of Cx43. These involve the direct exchange of substances between the cytosol and the extracellular space includin, e.g., the participation in the release of ATP and $\mathrm{NAD}^{+}, \mathrm{Ca}^{2+}$ wave propagation, and the passage of survival signals within the tissue via hemichannels. There is also evidence that even Cxs alone can display functions of intracellular signaling, independently from GJ formation (e.g., influence on directional cell migration and cell polarity, interactions with the cytoskeleton) mainly mediated by the cytoplasmic C-terminus $[5-7,28,53-56]$. However, there is evidence that small interfering RNAs can be transported via GJ to modulate gene expression in the target cell [57-61], and some findings in SCCx43KO were replicated by adding GJ blockers to an SC line in vitro [34], thus, it might be hypothesized that many effects of the deletion of $\mathrm{Cx} 43$ observed in SCCx43KO mice are channel-dependent. Conversely, there is evidence that also GCs regulate SC function and that this influence depends on the GC type and its particular requirements, but little is known about the role of GJ/Cx43 in this process [61-67]. It has been shown in vitro that GCs influence the protein synthesis of several tight junction proteins built by SC [61]. Similar results were shown by O'Shaughnessy et al. (2008), who investigated several SC specific mRNA transcripts after GC depletion in mice. Their results indicated that GC participate in regulating SC activity [66]. However, the mechanisms by which GC regulate SC activity are not clearly understood so far. Su et al. (2013) proposed a possible way to influence SC function by GC could be through transmitting small RNAs (microRNAs, small interfering RNAs, piwiinteracting RNAs) via GJ channels [61]. Recently, it has been shown in invertebrate testes that bi-directional GJ communication between soma and germ line is required for proper spermatogenesis $[68,69]$. All these data support a possible role for GJ in GC in regulating spermatogenesis also in vertebrates. However, the present results of the newly generated p- and mGCCx43KO mice indicate that Cx43 in spermatogonia/early spermatocytes or spermatids is not the key player in GC for these processes in mice. Still, heterotypic GJ, with Cx43-hemichannels from SC and GC-hemichannels built up by another Cx type, might be involved in the regulation of spermatogenesis (Figure 10). This model might be able to explain, why an $\mathrm{SC}$ specific $\mathrm{KO}$ of $\mathrm{Cx} 43$ results in such drastic effect on spermatogenesis and 
primarily affects GC $[31,33-37,44-46]$, while the $\mathrm{KO}$ of $\mathrm{Cx} 43$ does not seem to compromise spermatogenesis in mice with a GC specific $\mathrm{KO}$ of Cx43 [38].

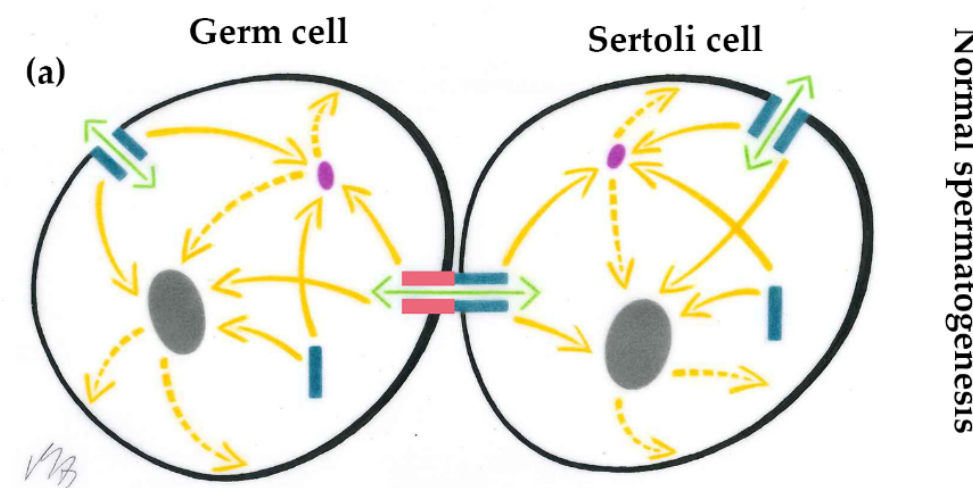

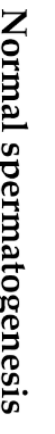
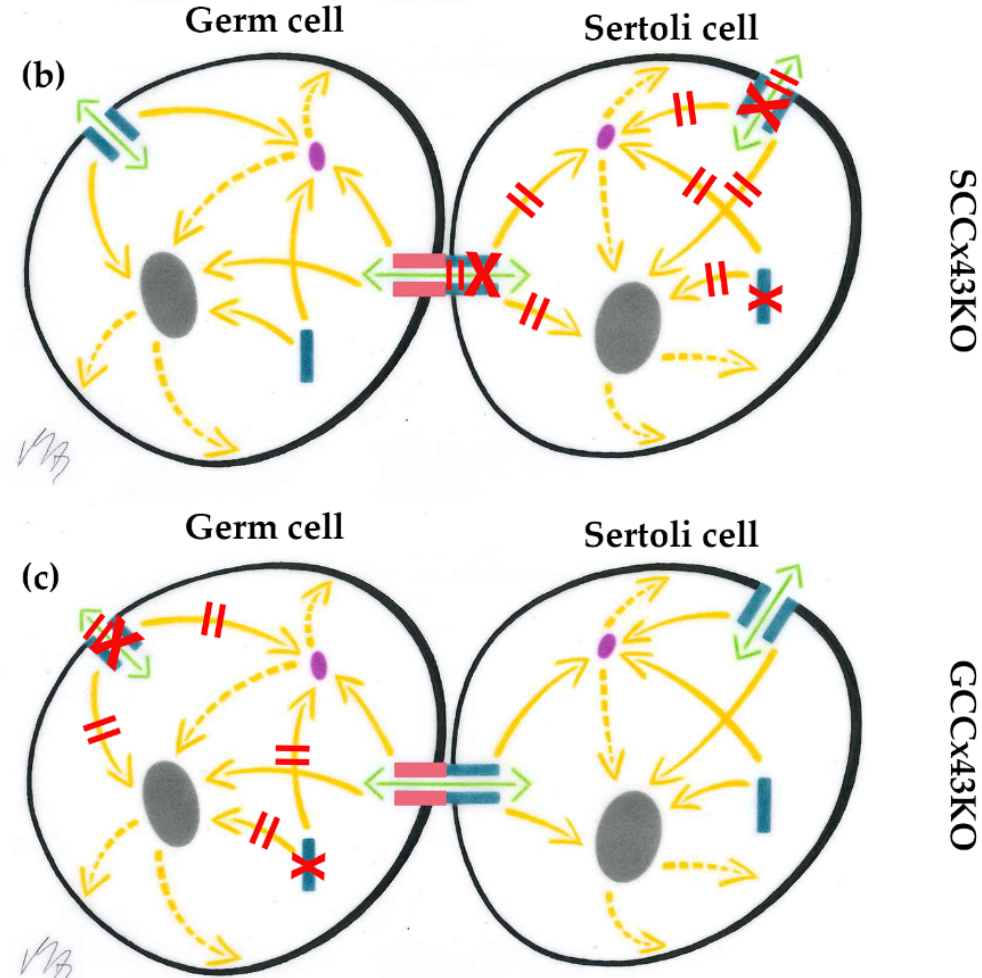

Legend:

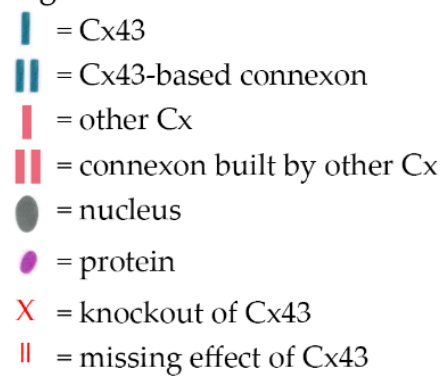

$\longleftrightarrow=$ gap junctional intercellular communication of coupled cells or paracrine intercellular communication by connexons (= hemichannels) $=$ channel-independent functions (e.g. regulation of gene expression or protein interactions)

Figure 10. Hypothetical explanatory model of heterotypic Sertoli cell (SC)-germ cell (GC) gap junctional intercellular communication (GJIC). (a) In wild type (WT) mice, GJIC is undisturbed resulting in normal spermatogenesis; (b) SC specific knockout (KO) of Cx43 leads to impaired GJIC between SC and GC as the Connexin43 (Cx43)-based hemichannel of the heterotypic gap junction channel is missing in SC specific Cx43 KO (SCCx43KO) mice; (c) GJIC via heterotypic hemichannels remains unaffected, when $\mathrm{Cx} 43$ is deleted in premeiotic or meiotic GC (GCCx43KO). 
Finally, the present results further underline the established idea that somatic SC and their Cx43-based GJ are crucial for GC development. Based upon the data of the present study and previous finding in SCCx43KO mice $[18,31-37,44-46]$, we hypothesize that SC and GC possibly communicate via heterotypic GJ composed of one Cx43-based SC-connexon and a GC-hemichannel constituted of a so far unknown Cx family member. Consequently, future investigations should focus on the exact composition of heterocellular GJ, linking SC and GC to identify possible binding partners in GC for Cx43-connexons of SC. A GC specific deletion of a potential binding partner in GC for SC-Cx43 hemichannels could elucidate, if there is another $\mathrm{Cx}$ member in GC, which can resemble the testicular phenotype of SCCx43KO mice.

\section{Materials and Methods}

\subsection{Animals}

Mice lacking the Cx43 gene (Gja1) solely in specific GC generations were generated using the Cre/loxP recombinase system [31,32]. This tool allows the generation of conditional mutant mice lacking a certain gene specifically in a targeted organ or cell type. The Cre (causes recombination)/loxP (locus of crossing over) recombinase system originates from the bacteriophage P1 and ensures an excision of a gene sequence flanked by two loxP-sites (so called "floxed" gene sequences) by the Cre recombinase [30]. It is based on mating two transgenic mouse lines, one of them having the target gene flanked by loxP sites, the other expressing the Cre recombinase under a cell/tissue specific promotor. Briefly, homozygous Cx43-floxed mice (Gja1 gene flanked by loxP sites) were mated with either Stra8-Cre mice (for Cx43 KO in premeiotic GC, pGCCx43KO mice) or Prm1-Cre mice (for $\mathrm{Cx} 43 \mathrm{KO}$ in meiotic GC, mGCCx43KO mice). Offspring (F1 generation: heterozyously Cx43-floxed and Cre positive) were then backcrossed with homozygously Cx43-floxed mice resulting in homozygously Cx43-floxed and either Cre-positive (considered as KO) or Cre-negative (considered as WT) offspring. All animal experiments were conducted according to the German Animal Protection Law and approved by the Lower Saxony State Office for Consumer Protection and Food Safety (decision 33.19-42502-04-17/2513, July 2017).

\subsection{PCR Genotyping}

Determination of the genotype was performed within the first 14 days post natum (p.n.) using ear tissue during the marking process of the animals. Genomic DNA was extracted from the tissue using Direct PCR tail reagent (VWR Life Science, catalogue no. 732-3256) according to the manufacturer's protocol and was analyzed for the expression of loxP-sites (Cx43-flox) and the Cre enzyme under specific promotors (primers are shown in Table 1). To analyze loxP-site expression, PCR conditions were set according to Brehm et al. (2007). Cre enzyme expression was investigated using the following PCR conditions; briefly, $1 \mu \mathrm{L}$ of gDNA was added to $5 \mu \mathrm{L}$ of $5 \times$ Green GoTaq $^{\circledR}$ Flexi buffer (Promega, Mannheim, Germany), $2 \mu \mathrm{L}$ of $\mathrm{MgCl} 2$ ( $25 \mathrm{mmol} / \mathrm{L}$; Promega), $0.5 \mu \mathrm{L}$ of dNTPs (Promega), $0.5 \mu \mathrm{L}$ of GoTaq $^{\circledR}$ Flexi DNA polymerase (Promega), $0.5 \mu \mathrm{L}$ of each primer $(10 \mu \mathrm{mol} / \mathrm{L}$; Eurofins Genomics, Ebersberg, Germany), and diethylpyrocarbonate (DEPC) $-\mathrm{H}_{2} \mathrm{O}$ to a final volume of $25 \mu \mathrm{L}$. Cycler programs were as follows for the amplification of Cre in the pGCCx43KO mouse line: $1 \times 95^{\circ} \mathrm{C}$ for $2 \mathrm{~min} ; 30 \times\left[95^{\circ} \mathrm{C}\right.$ for $1 \mathrm{~min}, 58^{\circ} \mathrm{C}$ for $2 \mathrm{~min}$, and $72{ }^{\circ} \mathrm{C}$ for 2 $\mathrm{min}$ ], $72{ }^{\circ} \mathrm{C}$ for $7 \mathrm{~min}$. For the Cre detection in mGCCx $43 \mathrm{KO}$ mice, PCR conditions were as follows: $1 \times 95^{\circ} \mathrm{C}$ for $2 \mathrm{~min} ; 35 \times\left[95^{\circ} \mathrm{C}\right.$ for $2 \mathrm{~min}, 60^{\circ} \mathrm{C}$ for $30 \mathrm{~s}$, and $72{ }^{\circ} \mathrm{C}$ for $\left.45 \mathrm{~s}\right], 72{ }^{\circ} \mathrm{C}$ for $7 \mathrm{~min}$. PCR products were separated in 1\% agarose gels and visualized with GelRed ${ }^{\circledR}$ (Biotrend, Köln, Germany). 
Table 1. Primers used for PCR genotyping, Connexin43 (Cx43)-del PCR and qRT-PCR.

\begin{tabular}{|c|c|c|c|c|c|}
\hline Name & Forward Primer $\left(5^{\prime}-3^{\prime}\right)$ & Reverse Primer $\left(5^{\prime}-3^{\prime}\right)$ & $\begin{array}{l}\text { Size of } \\
\text { Amplicon }\end{array}$ & Objective & Reference \\
\hline Cx43-flox & TCATGCCCGGCACAAGTGAGAC & TCACCCCAAGCTGACTCAACCG & $\begin{array}{l}1100 \mathrm{bp} \text { (flox) } \\
988 \mathrm{bp} \text { (WT) }\end{array}$ & Genotyping & [31] \\
\hline Stra-8 Cre & TCTGATGAAGTCAGGAAGAACC & GAGATGTCCTTCACTCTGATTC & $470 \mathrm{bp}$ & Genotyping & \\
\hline Prm1-Cre & AGGCAAATTTTGGTGTACGG & GTTCCCTCAGCAGCATTCTC & $405 \mathrm{bp}$ & Genotyping & \\
\hline Cx43-del & GGCATACAGACCCTTGGACTCC & TGCGGGCCTCTTCGCTATTACG & $670 \mathrm{bp}$ & Cx43-del PCR & [31] \\
\hline Gja1 (Cx43) & ACAGCGGTTGAGTCAGCTTG & GAGAGATGGGGAAGGACTTGT & $106 \mathrm{bp}$ & qRT-PCR & [37] \\
\hline $\begin{array}{c}\text { Gjc1 (Cx45) } \\
\text { NM_001001496.2 }\end{array}$ & CAGTTCTGGTGAACAGGGCA & ACAATCAGCACAGTGAGCCA & $125 \mathrm{bp}$ & qRT-PCR & \\
\hline $\begin{array}{c}\text { Gja6 (Cx33) } \\
\text { NM_001159382.1 }\end{array}$ & GCCAAGCTGCAAGAGTAGGA & CAAGTGAGTGCACACCTGAG & $138 \mathrm{bp}$ & qRT-PCR & \\
\hline Actb NM_007393.5 & CGCAGCCACTGTCGAGTC & GTCATCCATGGCGAACTGGT & $96 \mathrm{bp}$ & qRT-PCR & \\
\hline $\begin{array}{c}\text { Hsp90ab1 } \\
\text { NM } 008302.3\end{array}$ & GCTCCTTCGCTATCACACCT & TTGCTCTTTGCTCTCACCAGT & $121 \mathrm{bp}$ & qRT-PCR & \\
\hline Sox9 & CGGAGGAAGTCGGTGAAGA & GTCGGTTTTGGGAGTGGTG & $\begin{array}{l}810 \text { bp (gDNA) } \\
201 \text { bp (cDNA) }\end{array}$ & $\begin{array}{l}\text { DNAse digest } \\
\text { test }\end{array}$ & [70] \\
\hline
\end{tabular}

\subsection{Confirmation of the KO via Cx43-Del PCR}

Deletion of the Gja1 gene in testicular tissue was confirmed by Cx43-del PCR using gDNA from testes homogenate as previously described by Brehm and colleagues [31]. Primers are shown in Table 1.

\subsection{Tissue Sampling and Treatment}

Adult ( $>60$ days) male mice from both mouse lines were sacrificed by cervical dislocation after anesthesia with $\mathrm{CO}_{2}$. Testes were surgically removed and either placed into Bouin's solution for $48 \mathrm{~h}$ or snap frozen in liquid nitrogen and stored at $-80{ }^{\circ} \mathrm{C}$ until further processing. Bouin fixed tissue samples were embedded in paraffin and $4 \mu \mathrm{m}$ thick testicular sections were placed onto glass slides for either hematoxylin eosin (HE) staining or IHC/IF.

\subsection{Body and Testis Weights}

During dissection, body and total testis weight were determined and relative testis weight was calculated; per genotype 11 male mice were analyzed of the pGCCx43KO mouse line and five male mice per genotype of the mGCCx43KO mouse line.

\subsection{Testicular Histology}

For investigation of the testicular phenotype, HE stained testicular sections were analyzed via light microscopy (Zeiss Axioscope, Jena, Germany; Olympus DP 70 camera and Olympus DP Soft V3.2 software, Olympus Hamburg, Germany). Mean diameter of seminiferous tubules was determined of ten randomly selected round tubular cross sections in Bouin-fixed and HE-stained sections of three different adult KO and WT siblings of both $\mathrm{KO}$ mouse lines each.

\subsection{Immunohistochemistry and Immunofluorescence}

To visualize Cx43 localization in KO and WT testes, IHC was performed using a specific antibody. Furthermore, the SC-specific marker Sox 9 was used to accurately distinguish SC from GC and to determine their numbers. Antibodies, their dilutions and applications are shown in Table 2. 
Table 2. Antibodies used for immunohistochemistry (IHC) and Western blot (WB) analysis.

\begin{tabular}{|c|c|c|c|c|c|}
\hline Antibody & Host & Application & Dilution & Company & Catalogue No. \\
\hline Anti-Sox9 & Rabbit & IHC & $1: 800$ & Merck Millipore & AB5535 \\
\hline \multirow[t]{2}{*}{ Cx43 } & \multirow[t]{2}{*}{ Rabbit } & $\begin{array}{l}\text { IHC } \\
\text { IF }\end{array}$ & $1: 500$ & \multirow[t]{2}{*}{ Cell Signaling } & \multirow[t]{2}{*}{3512} \\
\hline & & WB & 1:1000 & & \\
\hline$\alpha$-Tubulin & Rabbit & WB & 1:1000 & Cell Signaling & 2125 \\
\hline 2nd Anti-Rabbit & Goat & WB & $1: 5000$ & Santa Cruz & SC-2004 \\
\hline $\begin{array}{c}\text { EnVision+ Single Reagent } \\
\text { (HRP Rabbit) }\end{array}$ & Goat & IHC & ready-to-use & Agilent Dako & K400311-2 \\
\hline 2nd Alexa 546 & & IF & 1:1000 & Invitrogen & A11010 \\
\hline
\end{tabular}

For IHC, Bouin-fixed and paraffin-embedded testicular $4 \mu \mathrm{m}$ section mounted on glass slides (Histobond, Paul Marienfeld, Laboratory Glassware, Lauda-Königshofen, Germany) were used. During deparaffinization and rehydration, the sections were incubated at room temperature in $196 \mathrm{~mL} \mathrm{80 \%} \mathrm{alcohol} \mathrm{containing} 4 \mathrm{~mL}$ of $30 \%$ hydrogen peroxide for $30 \mathrm{~min}$ to block endogenous peroxidase activity, followed by heat-induced antigen retrieval in sodium citrate buffer $\left(\mathrm{pH}\right.$ 6) at $96-99{ }^{\circ} \mathrm{C}$ for $20 \mathrm{~min}$. Afterwards, sections were blocked with phosphate-buffered saline (PBS) containing 3\% of bovine serum albumin (BSA) at room temperature for $20 \mathrm{~min}$ and incubated with the corresponding primary antibody at $4{ }^{\circ} \mathrm{C}$ overnight in a humidified chamber. Sections were then exposed to the compatible secondary antibody EnVision+ Single Reagent (HRP. Rabbit) for $30 \mathrm{~min}$ and immunoreactivity was visualized by the diaminobenzidine (DAB) detection system. After counterstaining with haematoxylin, sections were dehydrated and covered with Eukitt ${ }^{\circledR}$ (O. Kindler GmbH, Freiburg, Germany). For negative controls, the primary antibody was omitted and replaced by PBS.

Numbers of SC and GC per tubular cross section and GC:SC ratio were determined in immunohistochemically stained testicular sections using the primary anti-Sox 9 antibody. Per genotype, 45 randomly chosen round tubular cross sections of three different animals were analyzed and mean values were calculated.

For IF, Bouin-fixed and paraffin embedded testicular sections were deparaffinized and rehydrated, pretreated using citric buffer $\left(\mathrm{pH}\right.$ 6) for $20 \mathrm{~min}$ at $96-99^{\circ} \mathrm{C}$ and blocked using $3 \%$ BSA (in PBS) for $20 \mathrm{~min}$ at room temperature. The sections were incubated overnight with the primary antibody (see Table 2 ) at $4{ }^{\circ} \mathrm{C}$. The next day, sections were exposed to the fluorophore Alexa 546 (see Table 2) for $45 \mathrm{~min}$ at room temperature and mounted using Prolong ${ }^{\circledR}$ Gold Antifade Reagent Antifade (Invitrogen, Darmstadt, Germany, P36930). The sections were viewed under a Zeiss Axiovert 200M fluorescence microscope (Carl Zeiss, Oberkochen, Germany, Zeiss Axiovert 200M).

\subsection{Semi-Quantitative WB Analysis}

In order to confirm the specificity of antibodies used for IHC and to investigate whether relative protein amount of $\mathrm{Cx} 43$ was reduced in p- and mGCCx43KO testes, semi-quantitative WB analysis using testes homogenate of three mice per genotype was performed. To ensure that equal amounts of protein were investigated, $\alpha$-tubulin was used as a loading control. Antibodies and their dilutions used for WB analysis are shown in Table 2.

Proteins were extracted from testicular tissue using TRIzol ${ }^{\circledR}$ reagent following the manufacturer's instructions and were fractionated by SDS-PAGE (sodium dodecyl sulfate polyacrylamide gel electrophoresis) in a polyacrylamide gel at $150 \mathrm{~V}$ for $80 \mathrm{~min}$ with an amount of $20 \mu \mathrm{g}$ protein per lane. The PageRuler ${ }^{\mathrm{TM}}$ Prestained Protein Ladder 10-170 kDa (Fermentas, St. Leon-Rot, Germany) was used as a marker to determine molecular weight. Fractionated proteins were then blotted onto a Protran BA 85 nitrocellulose membrane (Whatman, Dassel, Germany) for $60 \mathrm{~min}$ at $1 \mathrm{~A} / \mathrm{cm}^{2}$ (PeqLab, Erlangen, Germany). After- 
wards, the membrane was blocked with 5\% non-fat skimmed milk in Tris-buffered saline and tween 20 (TBS-T) for $60 \mathrm{~min}$, followed by incubation with the primary antibody for Cx43 diluted in Tris buffered saline (TBS) over night at $4{ }^{\circ} \mathrm{C}$. The next day, the secondary goat-anti rabbit IgG-horseradish peroxidase (HRP) antibody was diluted 1:5000 in TBS and was applied for $45 \mathrm{~min}$ before the membrane was treated with the SuperSignal ${ }^{\circledR}$ West Dura Kit (Thermo Scientific, Schwerte, Germany) following the manufacturer's protocol. Finally, the membrane was photographed on a Bio 1D, Vilber (Lourmat, Eberhardzell, Germany). After that, the membrane was incubated twice in in stripping buffer for $30 \mathrm{~min}$ and the membrane was then incubated solely in TBS for the negative control at $4{ }^{\circ} \mathrm{C}$ over night. The next day, incubation with the secondary antibody, treatment with SuperSignal ${ }^{\circledR}$ West Dura Kit (Thermo Scientific, Schwerte, Germany), photographing and stripping of the membrane was repeated before the primary antibody of the loading control $\alpha$-tubulin was applied at $4{ }^{\circ} \mathrm{C}$ over night. Secondary antibody incubation, visualization and photography were repeated once more.

A semi quantitative analysis of $\mathrm{C} \times 43$ protein relative to the housekeeper (loading control) $\alpha$-tubulin was performed using the Bio-1D advanced software (Vilber Lourmat, Germany).

\section{9. $q R T-P C R$}

RNA extraction, reverse transcription and quantification gene of interest expression were performed as described in Schenke et al. [71] from testis samples of four mice per genotype with three technical raplicates each. Relative gene expression levels were calculated according to the $2^{\Delta \Delta C T}$ method [72]. Mean of the $\mathrm{Ct}$ values of the reference genes $A c t b$ and Hsp90ab1 was used for reference gene normalization for each sample as previously described $[38,44,45]$.

To test for successful DNAse digestion, cDNA samples were subjected to a Sox9 PCR. Sox 9 encodes for a SC specific transcription factor and the primers (see Table 1) used for the digest test are located on two different exons, so if the cDNA sample was contaminated with gDNA, the amplicon would be $810 \mathrm{bp}$, while the cDNA amplicon would only be $201 \mathrm{bp}$.

\subsection{Mating Experiments}

In order to test whether male $\mathrm{m}$ - and pGCCx43KO mice were fertile, homozygous $\mathrm{KO}$ of both mouse lines were mated with WT females (Janvier, C57BL/6JR) for up to six weeks.

\subsection{Statistical Analyses}

Significance was determined using a student's $t$-test or a Welch's test for samples with unequal variances for the comparison of tubular diameter, intratubular cell numbers, semi-quantitative WB analysis, and qRT-PCR. A $p$-value of $<0.05$ was defined as significant with * $p<0.05$.

Supplementary Materials: The following are available online at https:/ /www.mdpi.com/article/10 .3390/ijms22157924/s1.

Author Contributions: Conceptualization, K.R. and R.B.; methodology, K.R.; validation, B.S., M.L. and K.R.; formal analysis, K.R. and B.S.; investigation, K.R., M.L. and B.S.; resources, R.B. and B.S.; data curation, K.R.; writing — original draft preparation, K.R.; writing—review and editing, B.S. and R.B.; visualization, K.R. and B.S.; supervision, R.B.; project administration, K.R. and R.B. All authors have read and agreed to the published version of the manuscript."

Funding: This publication was supported by Deutsche Forschungsgemeinschaft and University of Veterinary Medicine Hannover, Foundation within the funding programme Open Access Publishing.

Institutional Review Board Statement: The study was conducted according to the German Animal Protection Law and approved by the Lower Saxony State Office for Consumer Protection and Food Safety (decision 33.19-42502-04-17/2513).

Informed Consent Statement: Not applicable. 
Data Availability Statement: The data presented in this study are available in Supplemental Tables S1-S3.

Acknowledgments: The authors thank Antoine Peters for providing the Stra8-Cre and Prm1-Cre mice. Further, the authors thank Doris Voigtländer, Alexander Krybus, Kerstin Rohn, Isabell Böckmann and Robert Schneider for their excellent technical support and Caren-Imme von Stemm for preparing the drawing artwork.

Conflicts of Interest: The authors declare no conflict of interest.

\section{References}

1. Kidder, G.M.; Cyr, D.G. Roles of connexins in testis development and spermatogenesis. Semin. Cell Dev. Biol. 2016, 50, 22-30. [CrossRef] [PubMed]

2. Pointis, G.; Gilleron, J.; Carette, D.; Segretain, D. Physiological and physiopathological aspects of connexins and communicating gap junctions in spermatogenesis. Philos. Trans. R. Soc. B Biol. Sci. 2010, 365, 1607-1620. [CrossRef] [PubMed]

3. 3Bruzzone, R.; White, T.W.; Paul, D.L. Review Connections with connexins: The molecular basis of direct intercellular sig-naling Eur. J. Biochem. 1996, 238, 1-27. [CrossRef] [PubMed]

4. Kumar, N.M.; Gilula, N.B. The Gap Junction Communication Channel. Cell 1996, 84, 381-388. [CrossRef]

5. Dbouk, H.A.; Mroue, R.M.; El-Sabban, M.E.; Talhouk, R.S. Connexins: A myriad of functions extending beyond assembly of gap junction channels. Cell Commun. Signal. 2009, 7, 4. [CrossRef]

6. Kotini, M.; Mayor, R. Connexins in migration during development and cancer. Dev. Biol. 2015, 401, 143-151. [CrossRef]

7. Elias, L.A.B.; Wang, D.D.; Kriegstein, A.R. Gap junction adhesion is necessary for radial migration in the neocortex. Nat. Cell Biol. 2007, 448, 901-907. [CrossRef]

8. Matsuuchi, L.; Naus, C.C. Gap junction proteins on the move: Connexins, the cytoskeleton and migration. Biochim. Biophys. Acta 2013, 1828, 94-108. [CrossRef]

9. Willecke, K.; Eiberger, J.; Degen, J.; Eckardt, D.; Romualdi, A.; Güldenagel, M.; Deutsch, U.; Söhl, G. Structural and Functional Diversity of Connexin Genes in the Mouse and Human Genome. Biol. Chem. 2002, 383, 725-737. [CrossRef]

10. Risley, M.S. Connexin gene expression in seminiferous tubules of the Sprague-Dawley rat. Biol. Reprod. 2000, 62, 748-754. [CrossRef] [PubMed]

11. Pelletier, R.M.; Pelletier, R.M. The distribution of connexin 43 is associated with the germ cell differentiation and with the modulation of the Sertoli cell junctional barrier in continual (guinea pig) and seasonal breeders' (mink) testes. J. Androl. 1995, 16, 400-409. [PubMed]

12. Pelletier, R.-M.; Byers, S.W. The blood-testis barrier and sertoli cell junctions: Structural considerations. Microsc. Res. Tech. 1992, 20, 3-33. [CrossRef] [PubMed]

13. Batias, C.; Siffroi, J.-P.; Fénichel, P.; Pointis, G.; Segretain, D. Connexin43 Gene Expression and Regulation in the Rodent Seminiferous Epithelium. J. Histochem. Cytochem. 2000, 48, 793-805. [CrossRef] [PubMed]

14. Bravo-Moreno, J.F.; Díaz-Sánchez, V.; Montoya-Flores, J.G.; Lamoyi, E.; Saéz, J.C.; Pérez-Armendariz, E.M. Expression of Connexin43 in mouse Leydig, Sertoli, and germinal cells at different stages of postnatal development. Anat. Rec. 2001, 264, 13-24. [CrossRef] [PubMed]

15. Pérez-Armendariz, E.M.; Lamoyi, E.; Mason, J.I.; Cisneros-Armas, D.; Luu-The, V.; Moreno, J.F.B. Developmental regulation of connexin 43 expression in fetal mouse testicular cells. Anat. Rec. 2001, 264, 237-246. [CrossRef]

16. Decrouy, X.; Gasc, J.; Pointis, G.; Segretain, D. Functional characterization of Cx43 based gap junctions during spermatogenesis. J. Cell. Physiol. 2004, 200, 146-154. [CrossRef]

17. Gilleron, J.; Carette, D.; Durand, P.; Pointis, G.; Segretain, D. Connexin 43 a potential regulator of cell proliferation and apoptosis within the seminiferous epithelium. Int. J. Biochem. Cell Biol. 2009, 41, 1381-1390. [CrossRef]

18. Noelke, J.; Wistuba, J.; Damm, O.S.; Fietz, D.; Gerber, J.; Gaehle, M.; Brehm, R. A Sertoli cell-specific connexin43 knockout leads to altered interstitial connexin expression and increased Leydig cell numbers. Cell Tissue Res. 2015, 361, 633-644. [CrossRef]

19. Kibschull, M.; Gellhaus, A.; Carette, D.; Segretain, D.; Pointis, G.; Gilleron, J. Physiological roles of connexins and pannexins in reproductive organs. Cell. Mol. Life Sci. 2015, 72, 2879-2898. [CrossRef]

20. Enders, G.C. Sertoli-Sertoli and Sertoli-Germ Cell Communications. In The Sertoli Cell; Russell, L.D., Griswold, M.D., Eds.; Cache River Press: Clearwater, FL, USA, 1993; pp. 447-460.

21. Risley, M.; Tan, I.; Roy, C.; Saez, J. Cell-, age- and stage-dependent distribution of connexin43 gap junctions in testes. J. Cell Sci. 1992, 103, 81-96. [CrossRef] [PubMed]

22. Risley, M.S.; Tan, I.P.; Farrell, J. Gap junctions with varied permeability properties establish cell-type specific communication pathways in the rat seminiferous epithelium. Biol. Reprod. 2002, 67, 945-952. [CrossRef]

23. Godet, M.; Sabido, O.; Gilleron, J.; Durand, P. Meiotic progression of rat spermatocytes requires mitogen-activated protein kinases of Sertoli cells and close contacts between the germ cells and the Sertoli cells. Dev. Biol. 2008, 315, 173-188. [CrossRef] [PubMed]

24. Mittelbrunn, M.; Sánchez-Madrid, F. Intercellular communication: Diverse structures for exchange of genetic information. Nat. Rev. Mol. Cell Biol. 2012, 13, 328-335. [CrossRef] [PubMed] 
25. Dym, M.; Fawcett, D.W. Further Observations on the Numbers of Spermatogonia, Spermatocytes, and Spermatids Connected by Intercellular Bridges in the Mammalian Testis. Biol. Reprod. 1971, 4, 195-215. [CrossRef]

26. Reaume, A.; De Sousa, P.; Kulkarni, S.; Langille, B.; Zhu, D.; Davies, T.; Juneja, S.; Kidder, G.; Rossant, J. Cardiac malformation in neonatal mice lacking connexin43. Science 1995, 267, 1831-1834. [CrossRef] [PubMed]

27. Juneja, S.C.; Barr, K.J.; Enders, G.C.; Kidder, G.M. Defects in the Germ Line and Gonads of Mice Lacking Connexin431. Biol. Reprod. 1999, 60, 1263-1270. [CrossRef] [PubMed]

28. Francis, R.; Lo, C.W. Primordial germ cell deficiency in the connexin 43 knockout mouse arises from apoptosis associated with abnormal p53 activation. Development 2006, 133, 3451-3460. [CrossRef] [PubMed]

29. Roscoe, W.A.; Barr, K.J.; Mhawi, A.A.; Pomerantz, D.K.; Kidder, G.M. Failure of Spermatogenesis in Mice Lacking Connexin431. Biol. Reprod. 2001, 65, 829-838. [CrossRef]

30. Nagy, A. Cre recombinase: The universal reagent for genome tailoring. Genesis 2000, 26, 99-109. [CrossRef]

31. Brehm, R.; Zeiler, M.; Rüttinger, C.; Herde, K.; Kibschull, M.; Winterhager, E.; Willecke, K.; Guillou, F.; Lécureuil, C.; Steger, K.; et al. A Sertoli Cell-Specific Knockout of Connexin43 Prevents Initiation of Spermatogenesis. Am. J. Pathol. 2007, 171, 19-31. [CrossRef]

32. Sridharan, S.; Simon, L.; Meling, D.D.; Cyr, D.G.; Gutstein, D.E.; Fishman, G.; Guillou, F.; Cooke, P.S. Proliferation of Adult Sertoli Cells Following Conditional Knockout of the Gap Junctional Protein GJA1 (Connexin 43) in Mice1. Biol. Reprod. 2007, 76, 804-812. [CrossRef]

33. Weider, K.; Bergmann, M.; Giese, S.; Guillou, F.; Failing, K.; Brehm, R. Altered differentiation and clustering of Sertoli cells in transgenic mice showing a Sertoli cell specific knockout of the connexin 43 gene. Differentiation 2011, 82, 38-49. [CrossRef] [PubMed]

34. Carette, D.; Weider, K.; Gilleron, J.; Giese, S.; Dompierre, J.; Bergmann, M.; Brehm, R.; Denizot, J.-P.; Segretain, D.; Pointis, G. Major involvement of connexin 43 in seminiferous epithelial junction dynamics and male fertility. Dev. Biol. 2010, 346, 54-67. [CrossRef] [PubMed]

35. Gerber, J.; Weider, K.; Hambruch, N.; Brehm, R. Loss of connexin43 (Cx43) in Sertoli cells leads to spatio-temporal alterations in occludin expression. Histol. Histopathol. 2014, 29, 935-948.

36. Gerber, J.; Heinrich, J.; Brehm, R. Blood-testis barrier and Sertoli cell function: Lessons from SCCx43KO mice. Reproduction 2016, 151, R15-R27. [CrossRef]

37. Giese, S.; Hossain, H.; Markmann, M.; Chakraborty, T.; Tchatalbachev, S.; Guillou, F.; Bergmann, M.; Failing, K.; Weider, K.; Brehm, R. Sertoli-cell-specific knockout of connexin 43 leads to multiple alterations in testicular gene expression in prepubertal mice. Dis. Model. Mech. 2012, 5, 895-913. [CrossRef]

38. Günther, S.; Fietz, D.; Weider, K.; Bergmann, M.; Brehm, R. Effects of a murine germ cell-specific knockout of Connexin 43 on Connexin expression in testis and fertility. Transgenic Res. 2012, 22, 631-641. [CrossRef]

39. Lomeli, H.; Ramos-Mejia, V.; Gertsenstein, M.; Lobe, C.G.; Nagy, A. Targeted insertion of Cre recombinase into the TNAP gene: Excision in primordial germ cells. Genesis 2000, 26, 116-117. [CrossRef]

40. Batias, C.; Defamie, N.; Lablack, A.; Thepot, D.; Fenichl, P.; Segretain, D.; Pointis, G. Modified expression of testicular gap-junction connexin 43 during normal spermatogenic cycle and in altered spermatogenesis. Cell Tissue Res. 1999, 298, 113-121. [CrossRef] [PubMed]

41. Sadate-Ngatchou, P.I.; Payne, C.J.; Dearth, A.T.; Braun, R.E. Cre recombinase activity specific to postnatal, premeiotic male germ cells in transgenic mice. Genesis 2008, 46, 738-742. [CrossRef] [PubMed]

42. Smith, L. Good planning and serendipity: Exploiting the Cre/Lox system in the testis. Reproduction 2011, 141, 151-161. [CrossRef]

43. O'Gorman, S.; Dagenais, N.A.; Qian, M.; Marchuk, Y. Protamine-Cre recombinase transgenes efficiently recombine target sequences in the male germ line of mice, but not in embryonic stem cells. Proc. Natl. Acad. Sci. USA 1997, 94, 14602-14607. [CrossRef]

44. Hilbold, E.; Distl, O.; Hoedemaker, M.; Wilkening, S.; Behr, R.; Rajkovic, A.; Langeheine, M.; Rode, K.; Jung, K.; Metzger, J.; et al. Loss of Cx43 in Murine Sertoli Cells Leads to Altered Prepubertal Sertoli Cell Maturation and Impairment of the Mitosis-Meiosis Switch. Cells 2020, 9, 676. [CrossRef]

45. Hollenbach, J.; Jung, K.; Noelke, J.; Gasse, H.; Pfarrer, C.; Koy, M.; Brehm, R. Loss of connexin43 in murine Sertoli cells and its effect on blood-testis barrier formation and dynamics. PLoS ONE 2018, 13, e0198100. [CrossRef]

46. Rode, K.; Weider, K.; Damm, O.S.; Wistuba, J.; Langeheine, M.; Brehm, R. Loss of connexin 43 in Sertoli cells provokes postnatal spermatogonial arrest, reduced germ cell numbers and impaired spermatogenesis. Reprod. Biol. 2018, 18, 456-466. [CrossRef]

47. Weider, K.; Bergmann, M.; Brehm, R. Connexin 43: Its regulatory role in testicular junction dynamics and spermatogenesis. Histol. Histopathol. 2011, 26, 1343-1352.

48. Pelletier, R.-M.; Akpovi, C.D.; Chen, L.; Day, R.; Vitale, M.L. CX43 expression, phosphorylation, and distribution in the normal and autoimmune orchitic testis with a look at gap junctions joining germ cell to germ cell. Am. J. Physiol. Regul. Integr. Comp. Physiol. 2011, 300, R121-R139. [CrossRef] [PubMed]

49. Pointis, G.; Fiorini, C.; Defamie, N.; Segretain, D. Gap junctional communication in the male reproductive system. Biochim. Biophys. Acta 2005, 1719, 102-116. [CrossRef] [PubMed]

50. Koval, M.; Molina, S.A.; Burt, J.M. Mix and match: Investigating heteromeric and heterotypic gap junction channels in model systems and native tissues. FEBS Lett. 2014, 588, 1193-1204. [CrossRef] 
51. Carette, D.; Gilleron, J.; Decrouy, X.; Fiorini, C.; Diry, M.; Segretain, D.; Pointis, G. Connexin 33 Impairs Gap Junction Functionality by Accelerating Connexin 43 Gap Junction Plaque Endocytosis. Traffic 2009, 10, 1272-1285. [CrossRef] [PubMed]

52. Rackauskas, M.; Kreuzberg, M.M.; Pranevicius, M.; Willecke, K.; Verselis, V.K.; Bukauskas, F.F. Gating Properties of Heterotypic Gap Junction Channels Formed of Connexins 40, 43, and 45. Biophys. J. 2007, 92, 1952-1965. [CrossRef] [PubMed]

53. Kameritsch, P.; Pogoda, K.; Pohl, U. Channel-independent influence of connexin 43 on cell migration. Biochim. Biophys. Acta 2012, 1818, 1993-2001. [CrossRef] [PubMed]

54. Plotkin, L.I.; Bellido, T. Beyond gap junctions: Connexin 43 and bone cell signaling. Bone 2013, 52, 157-166. [CrossRef]

55. Stout, C.; Goodenough, D.A.; Paul, D.L. Connexins: Functions without junctions. Curr. Opin. Cell Biol. 2004, 16, 507-512. [CrossRef]

56. Francis, R.; Xu, X.; Park, H.; Wei, C.-J.; Chang, S.; Chatterjee, B.; Lo, C. Connexin43 Modulates Cell Polarity and Directional Cell Migration by Regulating Microtubule Dynamics. PLoS ONE 2011, 6, e26379. [CrossRef]

57. Brink, P.R.; Valiunas, V.; Gordon, C.; Rosen, M.R.; Cohen, I.S. Can gap junctions deliver? Biochim. Biophys. Acta 2012, 1818, 2076-2081. [CrossRef]

58. Kanaporis, G.; Brink, P.R.; Valiunas, V. Gap junction permeability: Selectivity for anionic and cationic probes. Am. J. Physiol. Physiol. 2011, 300, C600-C609. [CrossRef]

59. Valiunas, V.; Polosina, Y.Y.; Miller, H.; Potapova, I.A.; Valiuniene, L.; Doronin, S.; Mathias, R.T.; Robinson, R.B.; Rosen, M.R.; Cohen, I.S.; et al. Connexin-specific cell-to-cell transfer of short interfering RNA by gap junctions. J. Physiol. 2005, 568, 459-468. [CrossRef] [PubMed]

60. Wolvetang, E.J.; Pera, M.F.; Zuckerman, K.S. Gap junction mediated transport of shRNA between human embryonic stem cells. Biochem. Biophys. Res. Commun. 2007, 363, 610-615. [CrossRef]

61. Su, L.; Kopera-Sobota, I.A.; Bilinska, B.; Cheng, C.Y.; Mruk, D.D. Germ cells contribute to the function of the Sertoli cell barrier An in vitro study. Spermatogenesis 2013, 3, e26460. [CrossRef]

62. Gearard, N.; Jegou, B. In-vitro influence of germ cells on Sertoli cel l-secreted proteins: A two-dimensional gel electrophoresis analysis. Int. J. Androl. 1993, 16, 285-291. [CrossRef] [PubMed]

63. Mruk, D.D.; Cheng, C.Y. Sertoli-Sertoli and Sertoli-Germ Cell Interactions and Their Significance in Germ Cell Movement in the Seminiferous Epithelium during Spermatogenesis. Endocr. Rev. 2004, 25, 747-806. [CrossRef] [PubMed]

64. Cheng, C.Y.; Mruk, D.D. Cell Junction Dynamics in the Testis: Sertoli-Germ Cell Interactions and Male Contraceptive Development. Physiol. Rev. 2002, 82, 825-874. [CrossRef]

65. Hermo, L.; Pelletier, R.-M.; Cyr, D.G.; Smith, C.E.; Pelletier, R. Surfing the wave, cycle, life history, and genes/proteins expressed by testicular germ cells. Part 5: Intercellular junctions and contacts between germs cells and Sertoli cells and their regulatory interactions, testicular cholesterol, and genes/proteins associated with more than one germ cell generation. Microsc. Res. Tech. 2009, 73, 409-494. [CrossRef]

66. O'Shaughnessy, P.J.; Hu, L.; Baker, P.J. Effect of germ cell depletion on levels of specific mRNA transcripts in mouse Sertoli cells and Leydig cells. Reproduction 2008, 135, 839-850. [CrossRef]

67. Griswold, M.D. Interactions Between Germ Cells and Sertoli Cells in the Testis. Biol. Reprod. 1995, 52, 211-216. [CrossRef]

68. Smendziuk, C.M.; Messenberg, A.; Vogl, A.W.; Tanentzapf, G. Bi-directional gap junction-mediated Soma-Germline communication is essential for spermatogenesis. Development 2015, 142, 2598-2609. [CrossRef] [PubMed]

69. Tazuke, S.I.; Schulz, C.; Gilboa, L.; Fogarty, M.; Mahowald, A.P.; Guichet, A.; Ephrussi, A.; Wood, C.G.; Lehmann, R.; Fuller, M.T. A germline-specific gap junction protein required for survival of differentiating early germ cells. Development 2002, 129, 2529-2539. [CrossRef]

70. Barrionuevo, F.; Bagheri-Fam, S.; Klattig, J.; Kist, R.; Taketo, M.M.; Englert, C.; Scherer, G. Homozygous Inactivation of Sox9 Causes Complete XY Sex Reversal in Mice1. Biol. Reprod. 2006, 74, 195-201. [CrossRef] [PubMed]

71. Schenke, M.; Schjeide, B.-M.; Püschel, G.P.; Seeger, B. Analysis of Motor Neurons Differentiated from Human Induced Pluripotent Stem Cells for the Use in Cell-Based Botulinum Neurotoxin Activity Assays. Toxins 2020, 12, 276. [CrossRef] [PubMed]

72. Livak, K.J.; Schmittgen, T.D. Analysis of relative gene expression data using real-time quantitative PCR and the 2(-Delta Delta C(T)) Method. Methods 2001, 25, 402-408. [CrossRef] [PubMed] 